\title{
DEEP WELL CARS EXCLUSIVELY FOR HIGH-CUBE 40' CONTAINERS ON HIGH-SPEED TRAINS
}

\author{
FRIEDER R. HAFERKORN \\ Fachhochschule Dortmund/University of Applied Sciences and Arts, Germany
}

\begin{abstract}
About $1 \%$ or $2 \%$ of the overall container traffic is run on the Iron Silk Road between Europe and China (with a long broad-gauge section Belarus-Russia-Kazakhstan and gantry crane transshipments in Brest and Khorgos) because trains are estimated to be faster and more reliable than container ships. There may be even a market for high-speed block trains for the most valuable and urgent $10 \%$ or 20 $\%$ of these containers being part of just-in-time production or trade chains. These containers are worth to be shipped at express timetables and protected in deep well cars from falling neither off ships nor off trains. (On 1 January 2019 MSC_Zoe lost 342 containers washed ashore on Dutch and German isles of the North Sea [1], and on 2 January 2019 a freight train lost an empty semi-trailer on the Great Belt Bridge in Denmark which caused a collision with a passenger train and 8 persons killed [2]). In UT conference, Sevilla 2002 [3], I was mistaken believing that there is no limit for mass or speed of container trains. A diagram on sustainable maximal speed $(\mathrm{Y})$ versus mass per length $(\mathrm{X})$ shows distinct sets for passenger trains near the $Y$ axis and freight trains near the $X$ axis and a cut set $<3 \mathrm{t} / \mathrm{m}$ and $\leq 120 \mathrm{~km} / \mathrm{h}$. So there are limits for both speed and mass per length, probably because of dynamic stress between train mass and infrastructure. In order to quickly develop a high-speed container train, existing and proven locomotives and bogies should be made use of and only the deep well car structure is left. Together with bogies and container masses, this structure must not exceed the mass-per-length criterion of a high-speed passenger middle car, to make the infrastructure not feel the difference. For easy and fast unloading and loading containers by gantry cranes, deep well cars should stay topless and be designed exclusively for high-cube $40^{\prime}$ containers. First estimates seem to confirm a compound welded copper-steel alloy structure will be tough, long and light enough. A market analysis, a feasibility study including air resistance and a specification book are required before prototypes of the car body can be designed, calibrated and manufactured for tests and presentations.
\end{abstract}

Keywords: Iron Silk Road, high-speed container train, deep well cars, mass-per-length vs. speed diagram, gantry crane transshipment

\section{INTRODUCTION}

To find out why some freight trains/vehicles are allowed for $120 \mathrm{~km} / \mathrm{h}$ ('ss'), some only for $100 \mathrm{~km} / \mathrm{h}$ ("s") and others not even, and why passenger trains normally are allowed for far more (Breimeier [4]), I checked literature (Table 1 and Fig. 2). Displaying sustainable maximal velocity $(\mathrm{Y})$ against mass per length $(\mathrm{X})$, there is a point cloud with clear sets for passenger trains along the $\mathrm{Y}$ axis, freight trains/vehicles along the $\mathrm{X}$ axis, a cut set and a large no-go area outside (Fig. 1).

In 2002 UT 8 conference in Sevilla [3], I talked about CargoSprinter/Talion container railcars ([5], [6], [7]) which are found in the cut set of Fig. 1, the lighter ones with $120 \mathrm{~km} / \mathrm{h}$ and the heavier ones with $100 \mathrm{~km} / \mathrm{h}$. I also proposed a streamlined and strongly motorised container train AeroSprinter bearing 2 containers 40' on the same frame $(4 \mathrm{t} / \mathrm{m})$ and hoped it would run $230 \mathrm{~km} / \mathrm{h}$ ([3], p. 695). With these values, AeroSprinter 2002 lands right in the no-go area of Fig. 1, sorry! Keeping the cargo load, AeroSprinter $2020 \mathrm{might}$ run $100 \mathrm{~km} / \mathrm{h}$. But if the heavy-driven middle bogie was cancelled and traction was concentrated to locomotives, load was lightered to one container per frame, cars or the distances between cars would become longer; if there were deep well cars with lower centre of gravity and better air flow, then AeroSprinter might regain $230 \mathrm{~km} / \mathrm{h}$ or more. 
Table 1: Data for the trains and vehicles displayed in Figs. 1 and 2.

\begin{tabular}{|c|c|c|c|c|}
\hline Type & {$[\mathrm{m}]$} & [t] & {$[\mathrm{t} / \mathrm{m}]$} & {$[\mathrm{km} / \mathrm{h}]$} \\
\hline \multicolumn{5}{|c|}{ Freight cars DR/DB [2]: } \\
\hline Fad 169 & 12.81 & 64.9 & 5.07 & 80 \\
\hline Hbis 298 & 14.02 & 40.8 & 2.91 & 100 \\
\hline Habiss 345 & 21.70 & 80.0 & 3.68 & 120 \\
\hline Laae 540 & 22.12 & 39.7 & 1.80 & 80 \\
\hline Laeqrss 548 & 26.24 & 45.4 & 1.73 & 120 \\
\hline Laaes 549 & 113.74 & 151.3 & 1.33 & 100 \\
\hline Saads 704 & 31.87 & 126.5 & 3.97 & 100 \\
\hline Sdkms(s) 707 & 16.44 & 51.5 & 3.13 & 120 \\
\hline Sahs 711 & 16.40 & 95.8 & 5.84 & 100 \\
\hline Sgjs(s) 716 & 21.08 & 79.7 & 3.78 & 120 \\
\hline Tefhss & 11.74 & 39.0 & 3.32 & 120 \\
\hline TT.nhhrs 19 & 16.27 & 65.5 & 4.03 & 100 \\
\hline Ibblpqrs & 14.02 & 39.7 & 2.83 & 100 \\
\hline Fals 183 & 12.54 & 89.8 & 7.16 & 100 \\
\hline Eas 5951 & 14.04 & 80 & 5.70 & 100 \\
\hline \multicolumn{5}{|c|}{ Soviet Highboard cars [3]: } \\
\hline 4-axles & 13.92 & 83.0 & 5.96 & 100 \\
\hline 6-axles & 16.40 & 126.0 & 7.68 & 100 \\
\hline 8-axles & 20.24 & 167.8 & 8.29 & 100 \\
\hline
\end{tabular}

\begin{tabular}{|c|c|c|c|c|}
\hline Type & [m] & [t] & {$[\mathrm{t} / \mathrm{m}]$} & {$[\mathrm{km} / \mathrm{h}]$} \\
\hline \multicolumn{5}{|c|}{ Shinkansen family [4]: } \\
\hline $\mathrm{A}$ & 49.5 & 120 & 2.42 & 250 \\
\hline B & 99.5 & 240 & 2.41 & 250 \\
\hline 0,16 cars & 400.3 & 967 & 2.42 & 220 \\
\hline 961 & 150.3 & 351 & 2.34 & 260 \\
\hline 962 & 150.3 & 348 & 2.32 & 210 \\
\hline 200,16 cars & 400.3 & 1,088 & 2.72 & 240 \\
\hline 100 & 402.1 & 925 & 2.30 & 230 \\
\hline 2000 & 402.1 & 1,088 & 2.71 & 275 \\
\hline 300 & 402.1 & 710 & 1.77 & 270 \\
\hline 400 & 128.2 & 312 & 2.44 & 240 \\
\hline WIN 350 & 151.6 & 230 & 1.52 & 350 \\
\hline \multirow{2}{*}{\multicolumn{5}{|c|}{ Others [4]: }} \\
\hline & & & & \\
\hline HST/IC-125 & 220 & 435 & 1.98 & 201 \\
\hline ICE 1 & 410.7 & 911 & 2.22 & 250 \\
\hline ICE 2 & 205.0 & 412 & 2.01 & 260 \\
\hline Velaro family & 250.0 & 667 & 2.67 & 250 \\
\hline \multicolumn{5}{|l|}{ Special examples: } \\
\hline $300 \mathrm{X}$ & 152.0 & 210 & 1.38 & 400 \\
\hline Parcel-IC & 197.4 & 525 & 2.66 & 160 \\
\hline CS/T-Long & 118.2 & 308 & 2.61 & 120 \\
\hline CS-Light & 90.4 & 233 & 2.58 & 120 \\
\hline CargoSprinter & 90.4 & 281 & 3.11 & 100 \\
\hline Talion-Light & 90.4 & 238 & 2.63 & 120 \\
\hline Talion & 90.4 & 286 & 3.16 & 100 \\
\hline Container Train & 259.4 & 840 & 3.24 & 100 \\
\hline CargoMover Train & 259.4 & 940 & 3.62 & 90 \\
\hline WELL cars (USA) & 174.4 & 830 & 4.76 & 112 \\
\hline FLAT cars (India) & 135.6 & 863 & 6.36 & 100 \\
\hline empty Uaai 839 & 50.3 & 263 & 5.22 & 80 \\
\hline Uaai 839 & 63.8 & 717 & 11.23 & 65 \\
\hline \multicolumn{5}{|l|}{ Projects: } \\
\hline AeroSprinter-Railcar & 407 & 628 & 1.54 & 350 \\
\hline AeroSprinter-Long & 370 & 754 & 2.04 & 310 \\
\hline AeroSprinter-BC & 305 & 716 & 2.35 & 270 \\
\hline AeroSprinter-A & 305 & 736 & 2.41 & 230 \\
\hline Pocket Wagons+ & 255 & 871 & 3.41 & 160 \\
\hline AeroSprinter 2002 & 250 & 1,001 & 4.00 & 230 \\
\hline AeroSprinter 2020 & 250 & 1,001 & 4.00 & 100 \\
\hline
\end{tabular}

\begin{tabular}{|r|r|r|r|r|}
\hline Soviet or Russian Railcars [3]: & & \\
\hline DP-01-08 & 158.7 & 367 & 2.31 & 104 \\
\hline DP-1-10 & 78.9 & 138 & 1.75 & 120 \\
\hline DP-11/12 & 48.1 & 90 & 1.87 & 125 \\
\hline DP-14 & 70.2 & 161 & 2.29 & 160 \\
\hline DP-15 & 69.5 & 161 & 2.32 & 160 \\
\hline DP-21 & 73.6 & 165 & 2.24 & 120 \\
\hline ER-200-8 & 208.0 & 442 & 2.13 & 180 \\
\hline ER-200-14 & 364.0 & 787 & 2.16 & 180 \\
\hline Sokol-250 & 158.0 & 356 & 2.25 & 250 \\
\hline & & & & \\
\hline TGV family [4]: & & & & \\
\hline Paris-Sud-Est1 & 200.2 & 428 & 2.14 & 270 \\
\hline Paris-Sud-Est2 & 200.2 & 409 & 2.04 & 300 \\
\hline Atlantique & 237.6 & 479 & 2.02 & 300 \\
\hline Réseau & 200.2 & 388 & 1.94 & 320 \\
\hline Postal & 200.2 & 345 & 1.72 & 270 \\
\hline Eurostar & 394.0 & 752 & 1.91 & 300 \\
\hline Thalys PBKA & 200.2 & 416 & 2.08 & 320 \\
\hline Duplex & 200.2 & 380 & 1.90 & 320 \\
\hline Est-Européen & 200.2 & 423 & 2.11 & 320 \\
\hline & & & & \\
\hline
\end{tabular}

\section{A DIAGRAM SHOWS THERE IS ANOTHER CHANCE FOR HIGH-SPEED CONTAINER TRAINS}

Figures 1 and 2 and Table 1 show the relation between mass per length of train or vehicle, and the allowed maximal speed in every day service, sustainably. Table 1 refers to sources Behrends [8], Slezak [9] and Obermayer [10] where I found most of the vehicle and train data. Fastest train with $400 \mathrm{~km} / \mathrm{h}$ is Shinkansen 300-X [11], and heaviest vehicle is 32-axle 


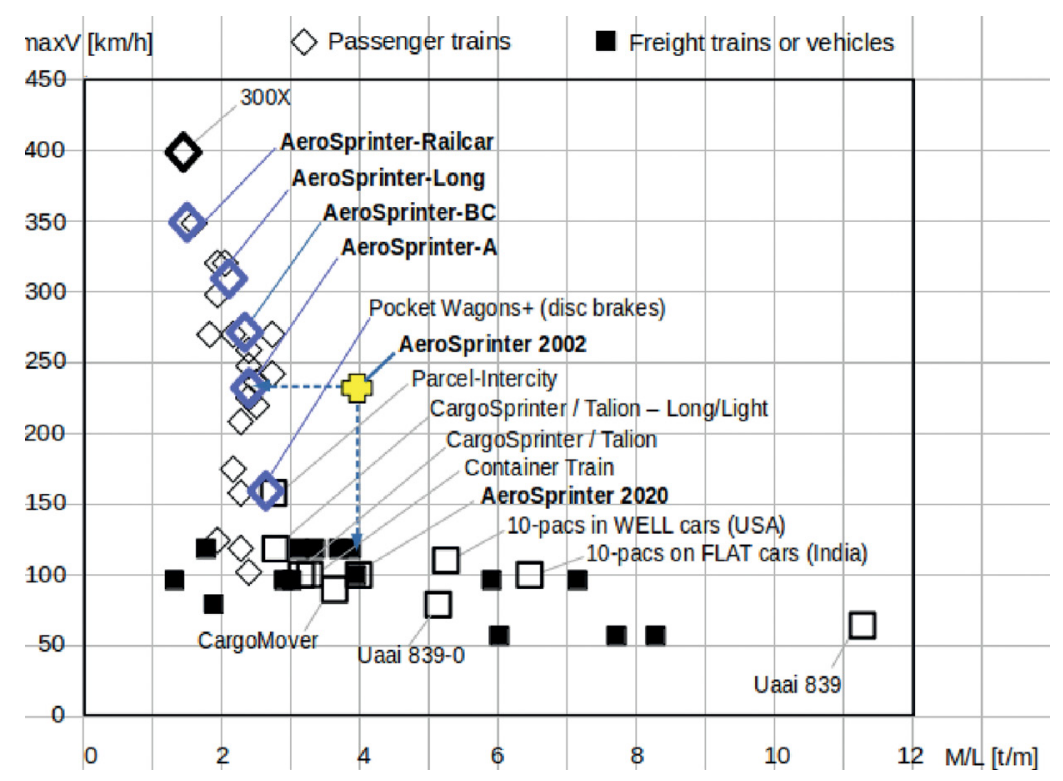

Figure 1: Passenger trains, freight trains (or vehicles), maxV as a function of mass per length $\mathrm{m} / 1[\mathrm{t} / \mathrm{m}]$.

Schnabel car Uaai 832 [3] carrying a transformer and allowed for $65 \mathrm{~km} / \mathrm{h}$ only. Within the freight train set, there are container cars/trains with 2 high-cube $40^{\prime}\left(\mathrm{HC}_{4} 0^{\prime}\right)$ containers on the same frame, articulated double-stack well cars [12] and short-coupled double stack flat cars [13]. Along the passenger set, I found the Parcel-IC with 2 swap bodies C782 (the mass of 1 container $40^{\prime}$, yet $2.50 \mathrm{~m}$ wide instead of $8^{\prime}$ ) on a $20 \mathrm{~m}$ car Sgss 703 ([14] and [5] p. 86). In its beginning, this train was allowed for $160 \mathrm{~km} / \mathrm{h}$.

CargoSprinter [6] and Talion [7] are found in the middle of the diagram within and near the cut set. Some of the CargoSprinter/Talion railcars were withdrawn, some are being used as rescue trains waiting at both ends of the Gotthard Base Tunnel and others were transformed to CargoMovers [15], automated and driverless collectors/distributors over short distances. By mere addition and division and like with a kit you may calculate mass, length and masslength quotient of a train out of the chosen rolling stock and see what maximal velocity might be allowed. With full container load $(3.11 \mathrm{t} / \mathrm{m})$, both CargoSprinter with usual 2-axle middle cars and Talion with articulated middle car are limited to $100 \mathrm{~km} / \mathrm{h}$. But with lightered middle cars bearing swap bodies C782 instead of 40' containers, they were allowed to run $120 \mathrm{~km} / \mathrm{h}$ because of only $2.63 \mathrm{t} / \mathrm{m}$. CargoSprinter-Talion lightered (CST-L) train shipping 40' containers on 4-axle middle cars Sggnss [16] (but only one container per car) would also be allowed to run $120 \mathrm{~km} / \mathrm{h}$ because of $2.61 \mathrm{t} / \mathrm{m}$, but with a longer train and gaps between the containers causing air resistance.

\section{SKETCHING A HIGH-SPEED TRAIN FOR HC40' CONTAINERS}

Not traction or brakes, signalling system or streamlining seem to be the reasons why freight trains are so much slower than passenger trains: There seems to be a principal interaction between train and infrastructure, probably above the wheel-track problems [17]: lighter trains $[\mathrm{t} / \mathrm{m}]$ are fit for high speed as heavier trains $[\mathrm{t} / \mathrm{m}]$ at high speed would wreck the 


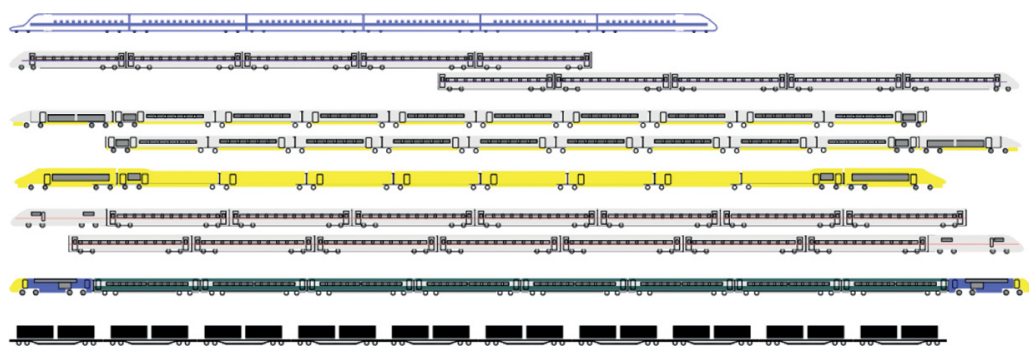

Figure 2a: Examples of the passenger train branch of Fig. 2, top-down: Shinkansen 300X: $400 \mathrm{~km} / \mathrm{h}$; Velaro-Sapsan: $360 \mathrm{~km} / \mathrm{h}$; TGV-EuroStar: $310 \mathrm{~km} / \mathrm{h}$; TGV-Postal: 270 km/h; ICE-1: 300 km/h; HST/IC-125: 201 km/h; Parcel-IC: 160 km/h.

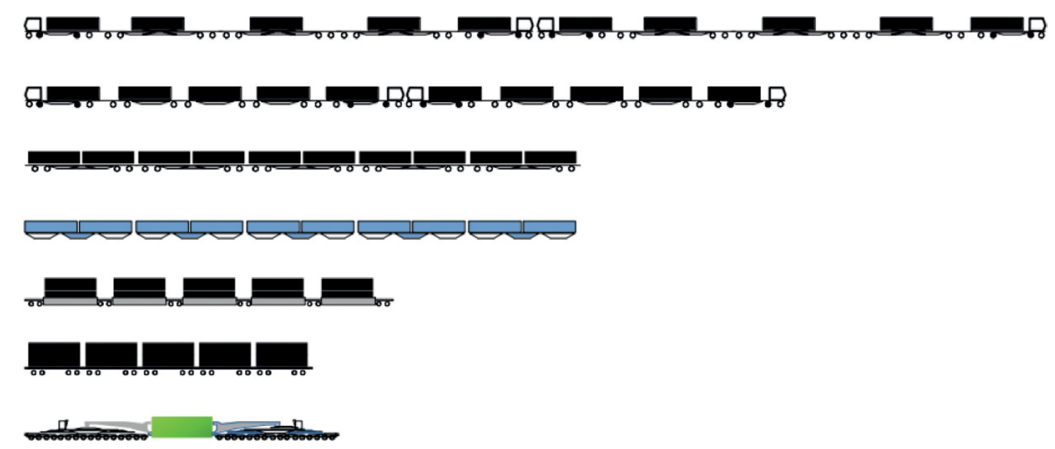

Figure 2b: The freight train branch of Fig. 2 (top-down): CargoSprinter/Talion-Long: 120 $\mathrm{km} / \mathrm{h}$; Talion: $100 \mathrm{~km} / \mathrm{h}$; Container Train: $120 \mathrm{~km} / \mathrm{h}$; AeroSprinter 2020: 100 $\mathrm{km} / \mathrm{h}$; Articulated well cars: $112 \mathrm{~km} / \mathrm{h}$; Short-coupled flat cars: $100 \mathrm{~km} / \mathrm{h}$; Schnabel car Uaai 839 with transformer: $65 \mathrm{~km} / \mathrm{h}$.

infrastructure, especially dams and bridges. So why not trick out the infrastructure by lightering container trains down to mass-per-length indices of passenger trains the infrastructure is used to?

Even some container trains have entered the passenger train territory, but flat cars or flat well cars do not seem safe enough for reliable high-speed operation. Containers have to be completely hidden in deep well cars, traction, brakes and signalling have to be concentrated to locomotives and bogies taken from passenger trains. So only one task is left: the bearing structure between container and bogie must be strong and long and deep and light enough to simulate a high-speed passenger train to the infrastructure.

\subsection{Existing or planned high-speed networks and trains}

In Europe, a high-speed network for standard gauge passenger trains has been developed connecting the UK via the Channel Tunnel, Scandinavia via the Öresund Bridge and Tunnel and Italy via the Gotthard Base Tunnel [4], [18]. For standard gauge passenger trains, there is another high-speed network in China. A high-speed line connects Istanbul with Ankara in Turkey. A Russian broad gauge high-speed line is driven between St. Petersburg and Moscow to be extended to Kazan and beyond. There is a plan to connect the capitals Moscow, Astana and Peking in only 30 hours [19]. 
Containers, however, mostly HC40', are shipped on long slow freight trains between China and Duisburg or Rotterdam or even farther westbound or southbound. For containers, there is no bogies exchange or wheelsets adjusting to overcome the gauge difference between standard and broad gauges. On the Iron Silk Road, containers are directly transshipped by normal gantry cranes once in Khorgos-Kazakhstan and once in Brest-Belarus.

A high-speed freight train called ICE-G is mentioned in the literature [10], and details are given in [5], p. 57. According to [20], there was a scale model of a freight version based on TGV-Duplex. The model shows a middle car with open side door giving view on pallets and air freight containers to be loaded and unloaded by fork lift. TGV-Postal [10], [20] that made to ship mail and parcels was operated many years on the French TGV high-speed network, but now out of service. Recently an Italian high-speed freight train called Mercitalia fast started operation. A video [21] shows it ships trolleys carrying parcels on modified passenger middle cars.

In GB high-speed passenger train HST-125/IC-125 (125 mph = $201 \mathrm{~km} / \mathrm{h})$ [10], [22] was withdrawn the other day, and in Russia Siemens Velaro Sapsan-250 [23] replaced the former high-speed trains Sokol-250 [24] and ER-200 [25] on the Moscow-St. Petersburg line. Together with the late TGV-Postal [10, 20], there seems to be a lot of rolling stock available to start a high-speed container train. Many problems as traction, braking, signalling system and gauge difference are already solved if locomotives, couplers and bogies may be used of existing or obsolete trains. To make the track not feel there is a container freight train rolling instead of a high-speed passenger train, nothing but a light and long and streamlined structure is required tough enough to bear one $\mathrm{HC}^{\prime} 0^{\prime}$ container between the bogies.

In the literature [26], [27], I found a manufacturer who offers high-speed bogies (Fig. 3) and well cars (Fig. 4). So it seems there is enough rolling material, bogies plus a manufacturer to create a deep well car body and compose a high-speed train to ship HC40' containers. And in [28], I found 75 pocket wagons for HC40' containers (Fig. 4, bottom).

\subsection{First design and calculation}

In Figs. 4 to 6, I tried do derive an outer form for a deep well car body from an ICE-Experimental middle car, $54 \mathrm{t}$ of which $11.5 \mathrm{t}$ for 2 bogies [10] p. 36. Both the well car structure
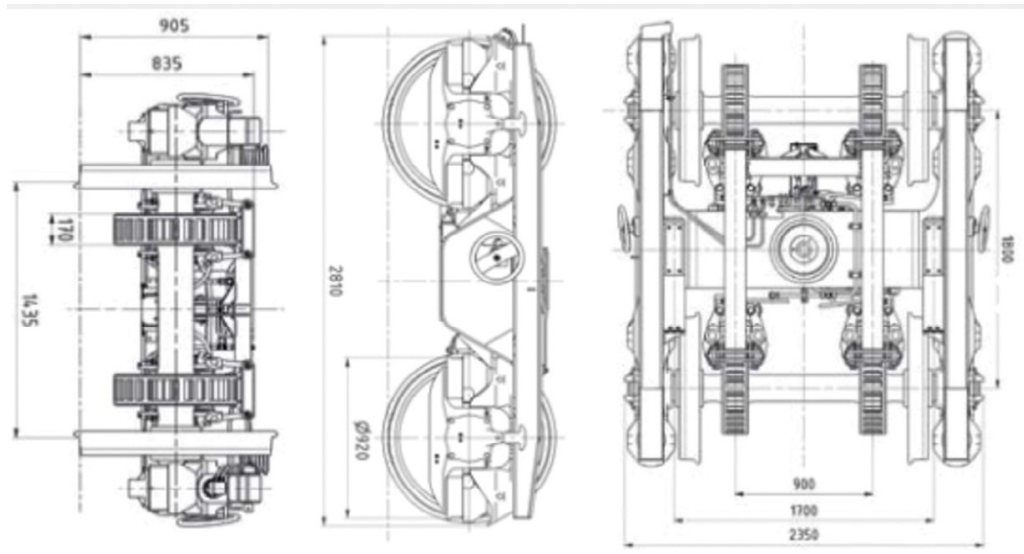

Figure 3: Disc brake Bogie DRRS 25LD type H, load per wheelset $\leq 25 \mathrm{t}$, mass $5 \mathrm{t}$, $\max V=120$ / $160 / 200 \mathrm{~km} / \mathrm{h}$. 

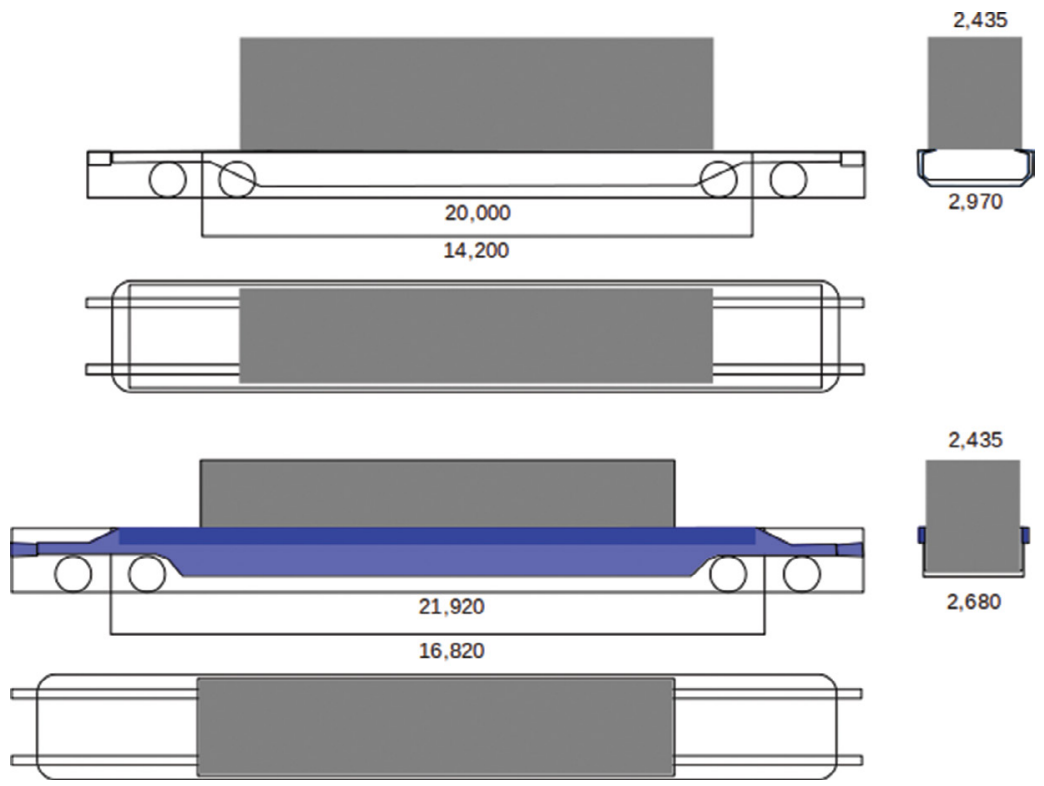

Figure 4: (Top) UIC well car Sdgnss [27], multipurpose but too short for 40', too wide for UK profile, and not streamlined, (bottom) UK loading gauge pocket wagon made for $\mathrm{HC}^{\prime} 0^{\prime}$ [28].
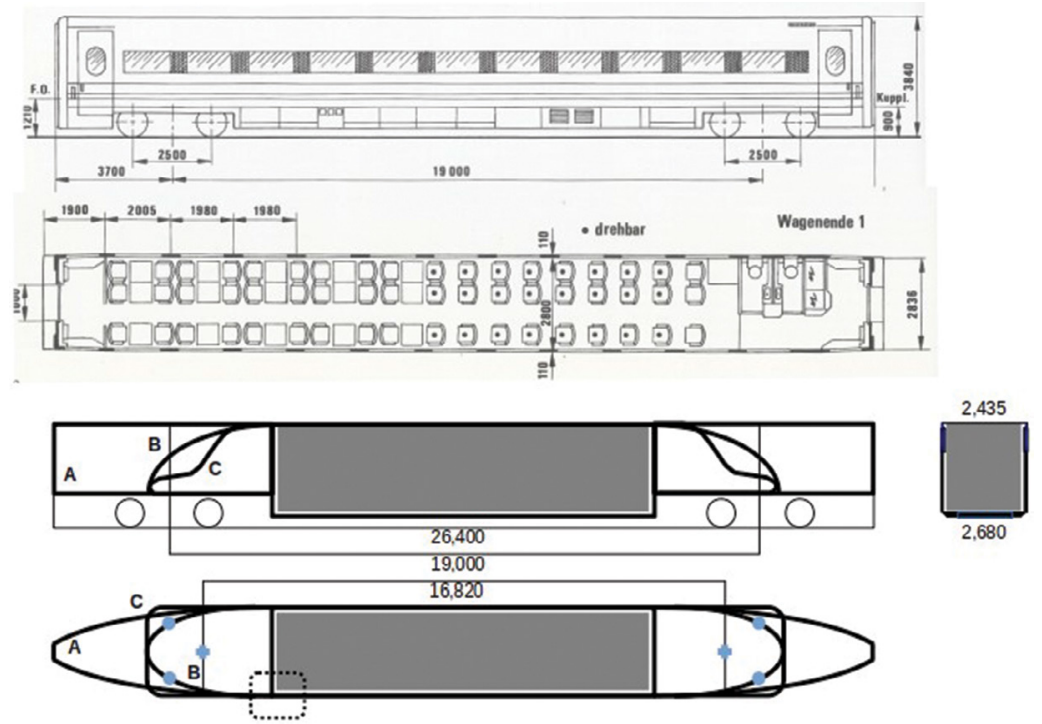

Figure 5: ICE middle car (top) and derived streamlined, narrow and low profile well cars AeroSprinter-A, AeroSprinter-BC and AeroSprinter-Long for one HC40' container and high-speed operation, also in GB (bottom). 


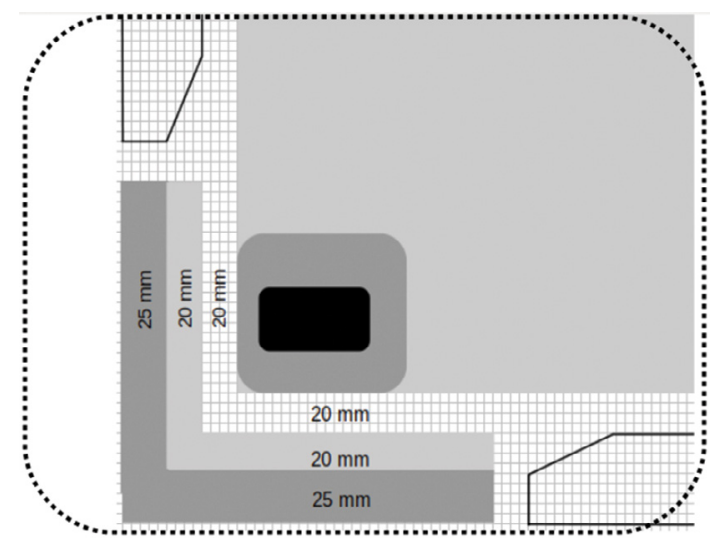

Figure 6: Detail of Fig. 5, showing there is only a 40-mm gap between container bottom and well car top.

mass of $11 \mathrm{t}$ and the container mass $31 \mathrm{t}$ totalling to $42 \mathrm{t}$, charge the framework main structure of the well car. This in turn helps to get an estimate of the steel profiles' areas and masses. Load case I divides $42 \mathrm{t}$ into $7 \times 6 \mathrm{t}$, II in $2 \times 21 \mathrm{t}$, and both III and IV keep the whole $42 \mathrm{t}$ concentrated, III in the centre and IV in the left most point of the structure.

The structure is made of a hollow profile skeleton inside and a sheet skin outside, all of copper-steel alloy S355J2, the former St $52 \mathrm{Cu}$, and welded. They were roughly calibrated, volumes and masses were calculated, and the result seems to confirm the structure will be both tough and light enough for shipping HC40' containers by high-speed trains.

\section{DERIVING SOME POINTS FOR A SPECIFICATION BOOK}

I am concerned if my assumptions on forces and masses will be confirmed by vehicle manufacturers because I did not yet consider dynamic stress, which surely has to be taken into account with the high velocities intended. The top chords may be under risk of kinking because of compressive stress, but the well cars that ship containers in the UK and USA give me some confidence. The bending moment resulting from $42 \mathrm{t}$ between the bogies (distance $19 \mathrm{~m}$ in ICE) is transferred to tension in the lower and compressive stress in the top chords according to the height distance between them. In my projected deep well car, this distance and moment of resistance will have about the double amounts compared with the ones in the UK and USA and so the pressure stress in deep well cars may be only about one half of the one in the flat well cars operating nowadays, but also velocities are different, 80 or 100 or $120 \mathrm{~km} / \mathrm{h}$ compared with 240 or even $360 \mathrm{~km} / \mathrm{h}$. Dynamic simulation [29] should tell if my concerns are justified.

\subsection{Safety aspects}

Figure 1 shows that container trains must not run faster than $160 \mathrm{~km} / \mathrm{h}(100 \mathrm{mph})$ even with mass-per-length quotients less than $3 \mathrm{t} / \mathrm{m}$, probably because with higher velocities twistlocks are estimated not to be safe enough to keep containers on the train.

For the safety aspects, containers have to be completely hidden in deep well cars. 
Freight cars do not require heavy and expensive comfort equipment like seats, toilets, air condition, gangway connections or Pendolino systems.

Bogies, couplers, brakes and traction have to be taken from passenger high-speed trains. To be allowed to operate on the same track and in the same schedule, container high-speed trains must not exceed the mass-per-length quotient of passenger high-speed trains, thus the infrastructure will not feel any difference.

Container well cars (together with only one container) must feature about the same massper-length quotient as high-speed passenger cars.

\subsection{Technical aspects}

The reason why only $1 \%$ or $2 \%$, the most important and valuable part of the freight between China and the EU is carried by train and not by ship is that rail transport is supposed to be much safer and far more reliable than sea transport, and faster. Twist-locks are made for transshipment and slow trains but not safe enough for high-speed transportation.
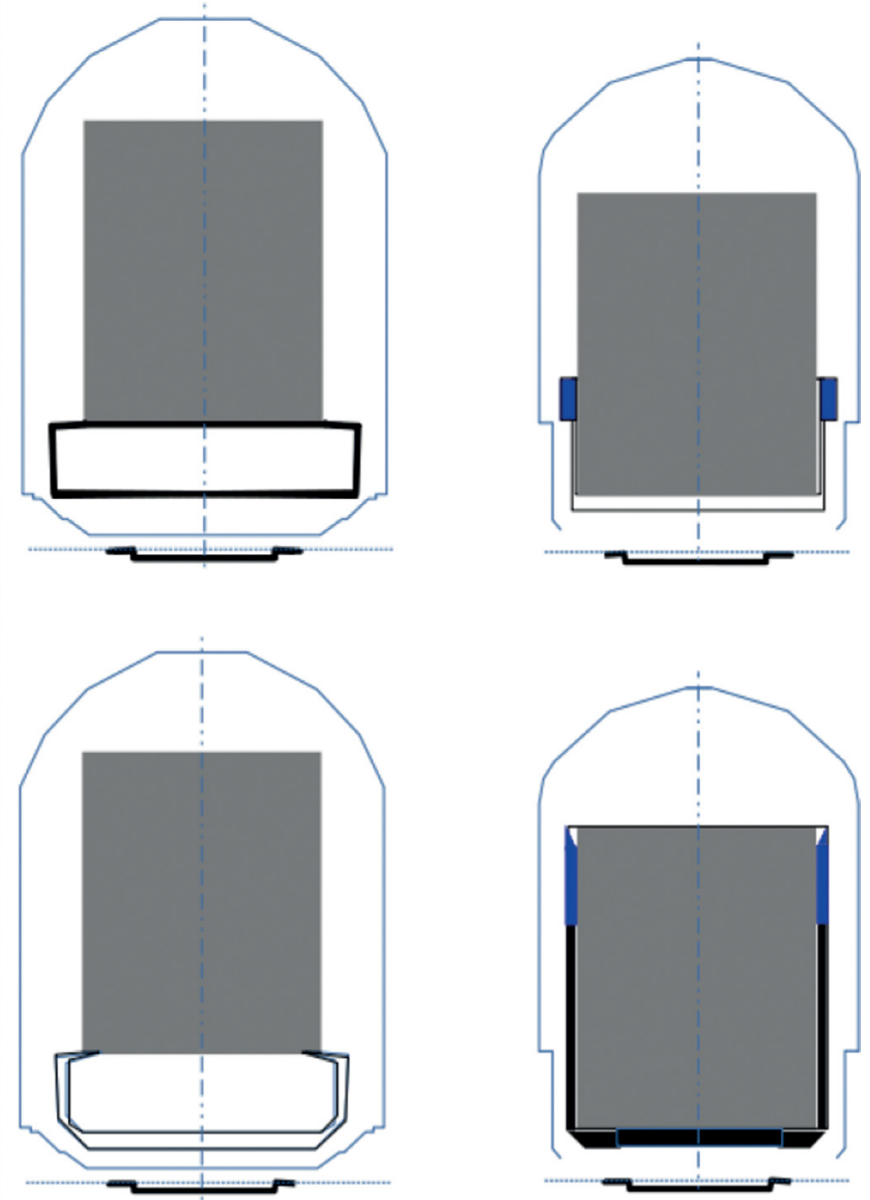

Figure 7: Loading gauge UIC ([30/8.1/1 $]$, International'): Flat car [16] (upper left); Well car [27] (lower left). Loading gauge UIC-UK ([30/8.8/1 $\left.{ }_{8}\right]$, Great Britain'): Pocket wagon [28] (upper right); deep well car of Fig. 5 (lower right). 
Car bodies have to close containers up to the top but stay topless for gantry crane transshipment. To enable easy and quick loading, transshipment (at gauge or other system borders) and unloading with gantry cranes and to keep car body structure light and simple without sliding roofs, e.g. deep well cars were chosen, which means topless without anything above the container load.

High-cube containers seem to become more and more popular to be observed with containers shipped by train between China and Duisburg or Rotterdam on Iron Silk Road. HC40' containers should be chosen as exclusive cargo for high-speed container trains to keep them uniform.

$$
\mathrm{F}_{\mathrm{w}}=\mathrm{c}_{\mathrm{w}} \times \mathrm{A} \times \rho / 2 \times \mathrm{v}^{2}
$$

$\mathrm{F}_{\mathrm{w}}[\mathrm{N}]$ flow resistance force; $\mathrm{c}_{\mathrm{w}}[4]$ flow resistance coefficient; $\mathrm{A}\left[\mathrm{m}^{2}\right]$ profile area; $\mathrm{v}[\mathrm{m} / \mathrm{s}]$ flow velocity; $\rho\left[\mathrm{N} / \mathrm{m}^{3}\right]$ density of air.

The above formula [3, p. 696] shows that flow resistance force of a vehicle depends directly of its profile area A, and there is no smaller loading gauge than UIC-UK [30/8.8], the one for British Railways. This is shown in Fig. 7, where profile areas of HC containers on flat cars (left) are compared with HC containers in well cars and pocket wagons (right). So HC40" well cars for high-speed container trains should obey to loading gauge UIC-UK.

Standard UIC-UK leaves only little room between container width and inner measures of deep well car bodies (Figs. 6 and 7), which is good for air resistance but may cause problems for gantry crane transshipment. Gantry crane operators should be offered some robotics or AI or at least video assistance.

\section{DERIVING A HIGH-SPEED TRAIN FOR HC40' CONTAINERS}

One idea to make the trains light and fast is to compose 2 and 2 of the Niesky bogies [26] to Jacobs type 4-axle bogies similar to the 2-axle ones connecting the middle cars (called 'remorques') of the TGV-Eurostar family. Jacobs bogies proved high stability when on 21 December 1993 TGV 001 derailed near Amiens with $300 \mathrm{~km} / \mathrm{h}$ and without any seriously injured passengers ([10] p. 107). Disadvantage of Jacobs bogies, usually 1, 2 or 3 axles, is that trains cannot be separated but in workshops, not so 4-axle Jacobs bogies. They support the adjacent car bodies by two axles each safely and may be easily separated at every train stop. Heavy and expensive couplers between middle cars are not required. Separable 4-axle Jacobs bogies may even be motorised to enable 10-car high-speed trains Shinkansen style with all axles driven, Velaro style with 8 axles and at least TGV/Eurostar style with 6 axles driven as shown in Fig. 8. They may also be expanded to sort of connecting flat cars or long couplers as with AeroSprinter-Long in Fig. 8 (top).

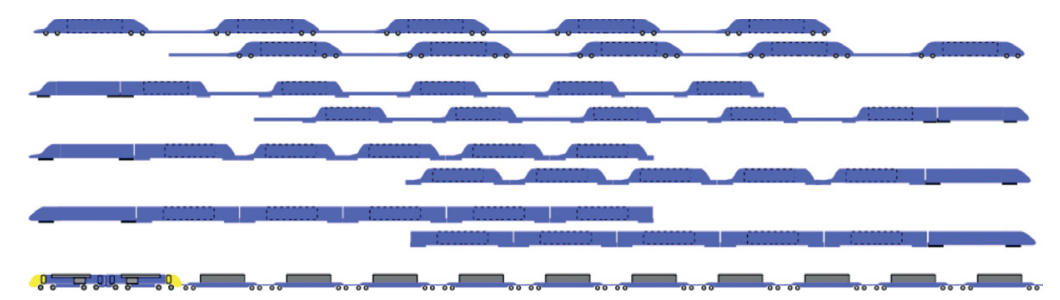

Figure 8: (Top-down): AeroSprinter-Railcar: $350 \mathrm{~km} / \mathrm{h}$; AeroSprinter-Long: $310 \mathrm{~km} / \mathrm{h}$; AeroSprinter-BC: 270 km/h; AeroSprinter-A: 230 km/h; PocketWagons+: $201 \mathrm{~km} / \mathrm{h}$. 
There is hope to speed up 75 pocket wagons for HC40' containers run in GB [28] by disk brake bogies, spoilers, distancers or 4-axle Jacobs bogies. But first of all we have to develop the deep well car body: safe, light and long and streamlined.

\section{CONCLUSIONS}

High-speed passenger trains are operating in many parts of the Eurasian Double Continent and its isles. There are, were and have been also high-speed trains for mail, parcels and luggage. In the literature [5] and [20], there is even a study model of a high-speed train for pallets and air freight containers derived from TGV-Duplex.

However freight trains carrying HC40' containers on flat cars or in well cars seem to be limited to not more than $160 \mathrm{~km} / \mathrm{h}$, probably because of too high masses concentrated on train length $[\mathrm{t} / \mathrm{m}]$ stressing the infrastructure. To make high-speed container transportation happen soon this paper suggests to use bogies, traction, brakes and signalling of existing passenger trains and to focus development on deep well car bodies. Of course, there are constraints and specifications to be observed, e.g.:

- Train masses have to be distributed along train length to $<3 \mathrm{t} / \mathrm{m}$.

- To prevent accidents by containers falling from the train at high-speed, they must be hidden in deep well cars.

- To keep air resistance low, only one container type and one container length must be shipped by high-speed Trains, exclusively HC40' containers.

- For low air resistance and Eurasia-wide operation deep well cars should follow the smallest loading gauge ever: UIC-UK.

- Gantry crane operators loading, transshipping and unloading containers should be assisted at least by video cameras as containers will fill up the volume of deep well cars almost completely.

- After discussion on this paper (theme: high-speed trains on standard gauge and broadgauge networks for HC40' containers in Eurasia), three studies should be started:

- A market analysis,

- A feasibility study including air resistance studies,

- A specifications book for well car body design, development and manufacturing.

Next, prototypes of the car body should be designed, calibrated, dynamically simulated and manufactured for tests and presentations.

\section{REFERENCES}

[1] 342 containers washed ashore: https://en.wikipedia.org/wiki/MSC_Zoe

[2] Freight train lost a semi-trailer: https://en.wikipedia.org/wiki/Great_Belt_Bridge_rail_ accident

[3] Haferkorn, F.R., "Container railcar versus container lorry transport - a comparative study", https://www.witpress.com/elibrary/wit-transactions-on-the-builtenvironment $/ 50 / 4147$

[4] Breimeier, R., Schnellere Güterzüge?, Eisenbahn Revue International 11/2008, p. 572.

[5] Gerhard Troche, ICE-G, Freight-TGV, TGV-Postal, Parcel-IC: https://www.kth.se/ polopoly_fs/1.87134.1550157093!/Menu/general/column-content/attachment/0512_ inlaga

[6] CargoSprinter: https://www.dybas.de/dybas/gw/gw_s_7/g700.html.

[7] Talion: https://www.dybas.de/dybas/gw/gw_s_7/g702.html. 
[8] Behrends, H./Hensel, W./Wiedau, G., "Güterwagen-Archiv 2", transpress 1989.

[9] J.-O. Slezak, "Breite Spur und weite Strecken", transpress 1963.

[10] Obermayer, H.J. (Ed.), "Internationaler Schnellverkehr - Superzüge in Europa und Japan”, Franck-Kosmos 1994.

[11] 300X: https://www.hochgeschwindigkeitszuege.com/japan/300-x.php.

[12] F.W. Frailey, Blue Streak Merchandise, Kalmbach 1991.

[13] Double-Stack on Flatcars: https://www.youtube.com/watch?v=6Rs5jzrk8wc.

[14] Parcel-IC: https://www.dybas.de/dybas/gw/gw_s_7/g703.html.

[15] CargoMover: https://www.dybas.de/dybas/index/c/cargo_mover.html.

[16] Container flatcar Sggns(s) 80: https://www.vtg.de/fileadmin/vtg/dokumente/waggondatenblaetter/Containerwagen-Sggns_s_80-I41.080D.pdf.

[17] Sato, Y., "Effect of intermediate beam in track on train induced ground vibration", https:// www.witpress.com/elibrary/wit-transactions-on-the-built-environment/74/12110, P. 809.

[18] Gotthard Base https://en.wikipedia.org/wiki/Gotthard_Base_Tunnel

[19] Beijing-Moscow in two days: https://www.rt.com/business/225131-russia-china-speedrailway/

[20] Papazian, A., Alles über den TGV, transpress 2007.

[21] Mercitalia...Fast: https://www.youtube.com/watch?v=UNzTiGxZYYk

[22] HST-125, IC-125: https://en.wikipedia.org/wiki/InterCity_125

[23] Sapsan: https://de.wikipedia.org/wiki/Siemens_Velaro.

[24] Sokol: https://ru.wikipedia.org/wiki/Сокол-250.

[25] ER-200: https://ru.wikipedia.org/wiki/ЭP200.

[26] HighSpeed freight car bogie (Niesky): https://www.waggonbau-niesky.com//assets/ files/downloads//WBN_Drehgestell_Datenblatt_dt.pdf.

[27] Wellcar (Niesky): www.waggonbau-niesky.com//assets/files/downloads//WBN Datenblatt_4achs. Taschenwagen Sdgnss.pdf.

[28] Pocket wagons: https://www.gwrr.co.uk/about/fleet/.

[29] Stichel, S., "The influence of underframe structural flexibility on the hunting behaviour of a freight wagon", https://www.witpress.com/elibrary/wit-transactions-on-the-builtenvironment/50/4156, p. 725.

[30] Loading gauges UIC and UIC-UK: https://uic.org/IMG/pdf/loading_rulesvolume_1-01042020.pdf 